US life scientists seek

\section{5 per cent rise to $\mathrm{NIH}$ research funds}

[WASHINGTON] The Federation of American Societies for Experimental Biology (FASEB) is calling for a 15 per cent increase in the budget of the National Institutes of Health (NIH) in 2000.

FASEB, which represents 56,000 researchers in 17 life-science societies, wants a \$2.3 billion boost for the biomedical agency, currently running on $\$ 15.6$ billion a year. This would bring its budget up to almost $\$ 18$ billion. The increase would keep the agency on track to double its budget over the five years from 1998 to 2003, as many of its supporters are advocating.

The federation issued the call last week in an annual report that also seeks a 15 per cent increase for the National Science Foundation, to $\$ 4.2$ billion. Meanwhile, in background material to President Clinton's State of the Union address on 19 January, the White House indicated that the president's forthcoming budget would ask Congress for only $\$ 320$ million in new funds for NIH about a 2 per cent increase.

If past patterns are any indication, Congress is likely to provide more than the White House requests. But it is not clear that, working within strict spending caps imposed by a 1997 budget law, Congress can or will produce a 15 per cent increase for the second year running. Last year, NIH landed a \$2 billion, 15 per cent increase.

FASEB president William Brinkley, a cell biologist who is vice-president for Graduate Sciences and dean of the Graduate School of Biomedical Sciences at Baylor College of Medicine in Houston, said he was confident of achieving the increase "because of the commitment of our [Congressional] champions", Congressman John Porter (Republican, Illinois) and Senator Arlen Specter (Republican, Pennsylvania).

Porter and Specter chair, respectively, the House and Senate appropriations subcommittees that fund NIH.

Brinkley said he felt confident that Porter was "committed" to achieving a 15 per cent NIH increase, since Porter had told FASEB officials recently: "It's going to be very difficult, but it can be done."

Brinkley and other FASEB officials are concerned that if $\mathrm{NIH}$ receives a significantly smaller increase, such as the amount the White House is requesting, the agency's ability to fund new investigator-initiated grants would fall off dramatically.

This is because so much of its money would already be committed to multi-year grants initiated in preceding years. The biomedical research agency is funding about 9,100 new grants this year. Meredith Wadman

\title{
Japan to try to understand quakes, not predict them
}

[TOКYO] Earthquake research in Japan should focus on understanding the mechanism of earthquakes, rather than predicting them, according to an advisory body to the Japanese prime minister. This shift is needed to develop new disaster prevention technologies.

The research plan was released last week by the Headquarters for Earthquake Research Promotion (HERP). It is intended to shape Japan's earthquake research for the next decade, and will influence projects at national research institutes from April, when the 1999 fiscal year begins.

There is a growing perception in Japan that successful earthquake prediction may not be realistic. Last year, the Geodetic Council, which advises the Ministry of Education, Science, Sports and Culture, made the first changes in its 30-year-old programme of attempting to predict imminent earthquakes, shifting its focus to long-term forecasts of areas likely to be struck by major tremors (see Nature 393, 202; 1998).

HERP's plan goes further by promoting research and development in disaster prevention techniques independent of earthquake prediction, and by emphasizing basic research on earthquake processes through satellite observation, for example with the global positioning systems.

Set up in 1995 after the Kobe earthquake to promote collaboration between ministries, universities and research institutes, HERP sees the main aim of its plan as exploring ways to minimize the effects of major earthquakes. It seeks to do this by analysis and simulation of seismic ground motions, and by creating a system to gather real-time seismic data.

While the plan emphasizes some earthquake prediction research, such as studies of the geophysical and geostructural features of seismogenic zones, it calls for a departure from techniques based on data collection. It states that accurately predicting the timing of earthquakes is "exceptionally difficult" with current technology.

"Although the prediction programme has shifted its focus to making long-term forecasts, there is still no guarantee that this is actually possible," says Mitsuhiro Matsuura, professor in seismology at Tokyo University. "The purpose of earthquake research is not to make a guess when an earthquake will strike, but to understand the scientific mechanism behind it."

The plan also calls for a new data centre to collect and analyse information related to domestic earthquake research. While its prime objective would be to provide information to researchers, it would also be accessible to the public.

By opening up this information, HERP hopes to give a better view of present research, and to prevent the exploitation of funds in the name of earthquake research, which is often generously funded and is said to be more likely to escape critical review.

But many researchers are concerned that disclosing data could mislead the public. "The disclosure of research data would certainly be beneficial to those involved in earthquake research, but it could cause misunderstanding among the public," warns Robert Geller, a seismologist at Tokyo University. "For example, the long-term absence of an earthquake in a particular region could give the residents a false sense of security."

The physics of earthquake processes, especially their dynamics, still requires detailed research, says Matsuura. Therefore the public must be given a careful explanation of seismological phenomena so people understand what happens. AsakoSaegusa

\section{China clamps down on inaccurate warnings}

[TOKYO] China has revealed plans to introduce tough regulations intended to stamp out 'false' earthquake warnings, in order to prevent panic and mass evacuations of cities triggered by forecasts of major tremors.

The new regulations on earthquake information, approved last week by the Chinese prime minister Zhu Rong-ji, will require a "high standard of scientific reasoning" behind all earthquake predictions. Anyone who releases an inaccurate earthquake warning may be penalized. According to the government, more than 30 unofficial earthquake warnings have been made in the past three years, none of which has been accurate. Such warnings, which could cause evacuation of more than 10,000 residents at a time, have repeatedly brought production lines and business operations to a standstill, leading not only to public disorder but also to considerable damage to the country's economy.

Earthquake prediction was introduced as a national priority in China during the Cultural Revolution, and warnings against the feasibility of such predictions - whether accurate or not were once seen as a challenge to Mao's revolutionary movement. A.s. 